\title{
Regional Analysis of NASA Satellite Greenness Trends for Ecosystems of Arctic Alaska
}

\author{
Christopher Potter \\ Mail Stop 232-21, Moffett Field, USA \\ Email: chris.potter@nasa.gov
}

Received 30 June 2014; revised 28 July 2014; accepted 21 August 2014

Copyright (C) 2014 by author and Scientific Research Publishing Inc.

This work is licensed under the Creative Commons Attribution International License (CC BY).

http://creativecommons.org/licenses/by/4.0/

(c) (i) Open Access

\section{Abstract}

Trends in the growing season MODerate resolution Imaging Spectroradiometer (MODIS) Enhanced Vegetation Index (EVI) time-series were analyzed for the period from 2000 to 2010 to understand landscape-level patterns of vegetation change in ecosystems of arctic Alaska. We compared datasets for vegetation cover types, wetland cover classes, wildfire boundaries since the 1940s, permafrost type, and elevation to identify the most likely combination of factors driving regional changes in habitat quality and ecosystem productivity. Approximately $57 \%$ of all arctic ecosystem areas in Alaska were detected with significant $(p<0.05)$ positive or negative MODIS growing season EVI trends from 2000 to 2010 . Nearly all (99\%) of these ecosystem areas (covering $178,050 \mathrm{~km}^{2}$ ) were detected with significant positive growing season EVI trends. The vast majority of the arctic Alaska region detected with significant positive growing season EVI trends was classified as upland tundra cover, although non-forested wetlands (marshes, bogs, fens, and floodplains) were co-located on $8 \%$ of that area. Herbaceous wetlands were co-located on $55 \%$ of the total area detected with significant negative growing season EVI trends, mostly on the arctic coastal plain and foothills. This evidence supports the hypothesis that temperature (warming) has markedly enhanced the rates of upland tundra vegetation growth across most of arctic Alaska over recent years.

\section{Keywords}

MODIS EVI, Arctic, Tundra, Wetlands, Wildfire, Alaska

\section{Introduction}

Major changes have been observed in Alaskan ecosystems over the past several decades, including rapidly 
melting ground ice (permafrost), ice wedge degradation, wetland drying, and increased shrub growth [1]-[4]. Along the arctic coastal plain of Alaska, permafrost temperatures have increased $5^{\circ} \mathrm{F}$ increase since the $1980 \mathrm{~s}$ [5]. Many areas in the continuous permafrost zone have seen increases in temperature in the seasonally active layer and a decrease in re-freezing rates. Alaska saw a 10\% increase in precipitation from 1949 to 2005, with the greatest increases recorded in winter snowfall [6]. The length of the growing season (photosynthetically active period) in the Arctic has increased by 9 days per decade since 1982 [7]. Snow cover variability may be an important cause of such phenological change in the arctic tundra. Zeng and Jia [8] found greening onset was related to final snowmelt date and the end of the growing season was strongly related to the date of first snow cover.

Satellite remote sensing has been used to effectively monitor changes in high-latitude vegetation cover and productivity, especially following disturbance [9]-[14]. Like many others, Goetz et al. [15] [16] analyzed the seasonal and inter-annual variations of post-fire forest cover by using the Advanced Very High Resolution Radiometer (AVHRR) normalized difference vegetation index (NDVI) time-series across boreal North America and reported vegetation compositional changes consistent with early successional plant species and susceptibility to drought. Kim et al. [17] examined changing soil freeze-thaw signal from satellite microwave remote sensing and vegetation greenness patterns for the 9-year (2000-2008) vegetation record from satellites over North America, and reported that the relationship between the non-frozen period (June-August) and mean summer greenness index anomalies was generally positive for tundra and boreal forests areas of Canada.

In this study, we analyzed trends in the NASA MODerate resolution Imaging Spectroradiometer (MODIS) Enhanced Vegetation Index (EVI) satellite data record over the time period from 2000 to 2010 to understand landscape-level patterns of vegetation change in ecosystems of arctic Alaska. MODIS offers significant advances over AVHRR in spatial resolution and spectral information, particularly with respect to correcting surface images for cloud contamination [18] in persistently cloudy regions like the Arctic. We compared datasets for Alaska vegetation cover types (from MODIS), wetland cover classes from Whitcomb et al. [19], wildfire boundaries since the 1940s, permafrost type, and elevation, all to improve interpretations of changes in EVI green vegetation cover. The main objective of this multilayer spatial analysis was to help identify the most likely combination of factors driving long-term changes in habitat quality and ecosystem productivity across the arctic Alaska region (Figure 1).

\section{Methods and Data Sets Used}

Collection 5 MODIS data sets beginning in the year 2000 were obtained from NASA's Land Processes Distributed Active Archive Center site (LP-DACC, 2007) [20]. As described by Li and Potter [13], MODIS EVI values were aggregated to 8-km resolution from MOD13C2 (MODIS/Terra Vegetation Indices) products. MOD13C2 data are cloud-free spatial composites of the gridded 16-day 1-kilometer MOD13A2 product, and were provided monthly as a level-3 product projected on a 0.05 degree (5600-meter) geographic Climate Modeling Grid (CMG). Quality assessment (QA) for a cloud-free global coverage at 8-km spatial resolution was achieved by replacing clouds with the historical MODIS time-series EVI record. MODIS EVI was calculated from red, blue and NIR bands as described by Huete et al. [21]. Monthly EVI values were summed across each growing season period (May through September) to represent the variability in vegetation productivity for these past 11 years.

MODIS EVI was scaled from its original values to a range of 0 to 1.0 for time-series regression analysis. Slope values indicated the change in summed growing season EVI per year over the period 2000 to 2010. Positive slope values indicated greening over time, whereas negative slope values indicated declining green vegetation cover from 2000 to 2010. According to the coefficient of determination $\left(R^{2}\right)$ of EVI time-based regressions, areas with a $95 \%$ statistical level of significance for a two-tailed t-test $\left(R^{2} \geq 0.37\right)$ consistently showed a negative or positive slope of greater than or equal to $0.02 \mathrm{EVI}$ units per year [13].

Vegetation cover classes from 2009 MODIS imagery (1-km resolution; Friedl et al. 2002 [22]) and the wetland map developed from satellite radar by Whitcomb et al. [19] were added to the EVI trend analysis (Figure 2). Wetland types (1-km resolution) were listed by Whitcomb et al. [19] as combinations of estuarine (tidal inlet), lacustrine (lakes), or palustrine (bogs and fens) with scrub/shrub, emergent, or moss/lichen vegetation cover. Permafrost types for Alaska were mapped originally by Ferrians [23] and regridded to 8-km spatial resolution for this analysis. Elevation at 1-km resolution was derived from the United States Geological Survey (USGS) National Elevation Dataset (NED). 


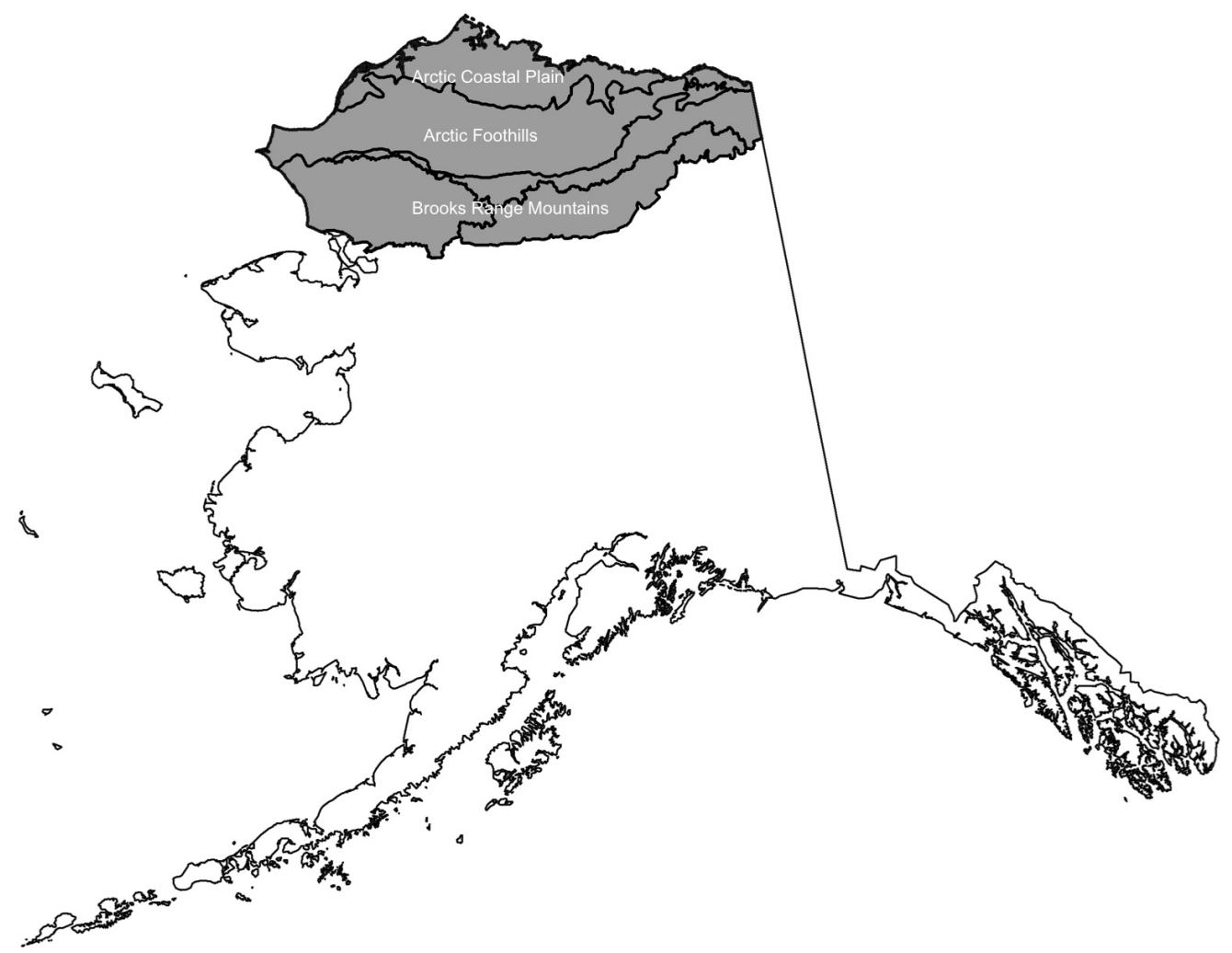

Figure 1. Major Land Resource Area (MLRA) coverage of arctic Alaska shown in the dark shaded areas.

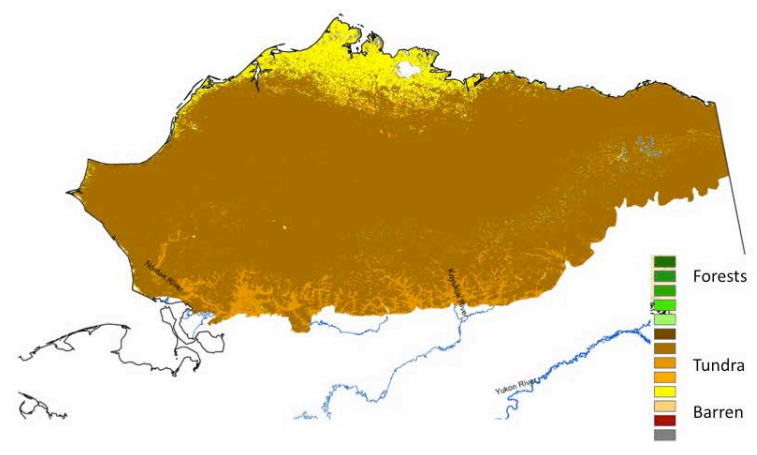

(a)

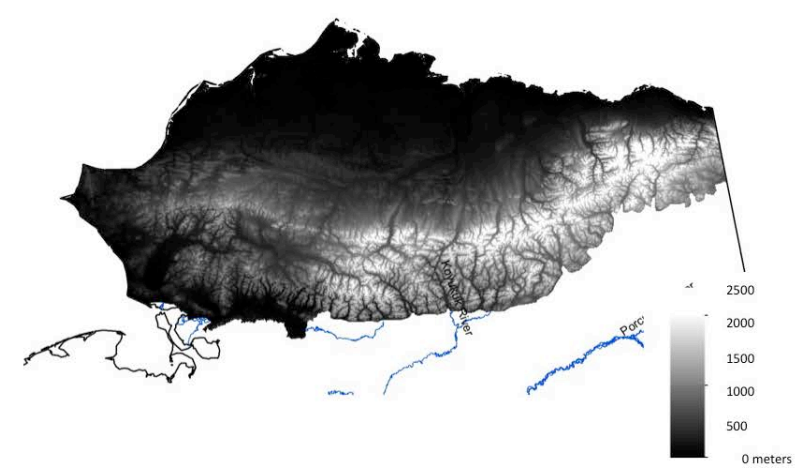

(c)

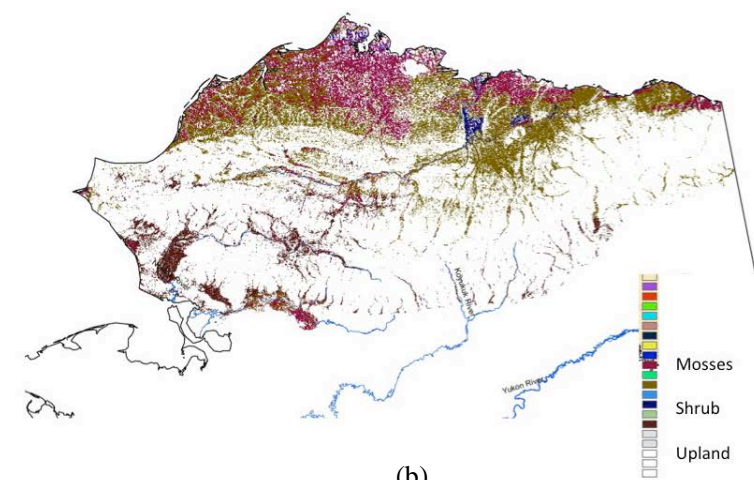

(b)

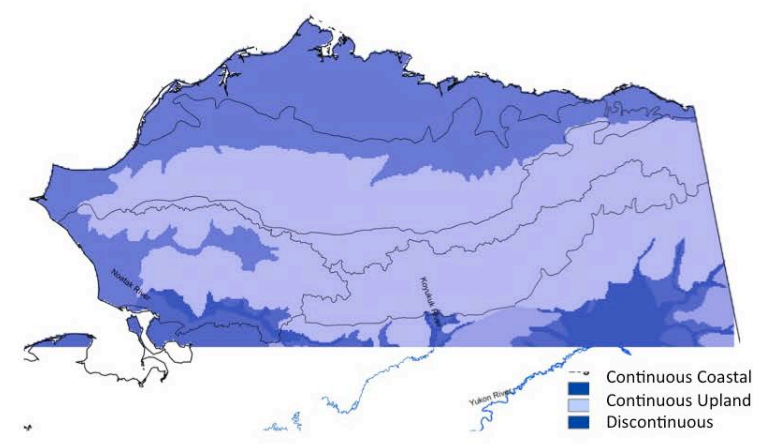

(d)

Figure 2. Regional maps of (a) land cover, (b) wetlands, (c) elevation, and (d) permafrost types of arctic Alaska. 
Areas burned by wildfires in interior Alaska since 1940 were delineated from the polygon boundary files of the Alaska Interagency Coordination Center (AICC) (available at http://afsmaps.blm.gov/imf_firehistory/). Prior to 1987, only fires in excess of 1000 acres (405 ha) coverage were included in this fire history database, whereas after 1987, all fires in excess of 100 acres (40.5 ha) were included.

\section{Study Region}

The Arctic zone is characterized generally by average annual precipitation of less than $50 \mathrm{~cm}$ and an average annual temperature of $-6^{\circ} \mathrm{C}$ or less [24]. The arctic region of Alaska was delineated for this study as a total area of 317,380 $\mathrm{km}^{2}$ within the Major Land Resource Areas [25] covering the Arctic Coastal Plain, Arctic Foothills, and Brooks Range Mountains (Figure 1). According to MODIS 1-km land cover mapping (Figure 2), this Alaskan arctic region is predominantly (99\%) open tundra cover, $0.1 \%$ evergreen (coniferous) forest cover, and $0.7 \%$ barren land cover. Wetlands, as identified by Whitcomb et al. [19], covered $28 \%\left(89,180 \mathrm{~km}^{2}\right)$ of the region, located mainly on the coastal plain, with $82 \%$ of these ecosystems classified as herbaceous and $18 \%$ as shrub covered wetlands across the region (Figure 2). About $85 \%$ of the region was located on continuous permafrost. Elevation across the region ranges from sea level on the coastal plain to $2500 \mathrm{~m}$ in the highest portions of Brooks Range Mountains. The AICC wildfire boundary record showed that only $1.4 \%\left(4563 \mathrm{~km}^{2}\right)$ of the Alaskan arctic region was burned by fires between 1940 and 2010. During the period between 2000 and 2010 alone, an area of $1707 \mathrm{~km}^{2}$ of the region was burned by wildfire, more than any other decade since before 1940 .

\section{Results}

Approximately 57\% (nearly 180,740 $\mathrm{km}^{2}$ ) of all area in arctic Alaska was detected with significant $(p<0.05)$ positive or negative MODIS growing season EVI trends from 2000 to 2010 (Figure 3). Nearly 99\% of these ecosystem areas were detected with significant positive growing season EVI trends.

\subsection{Negative EVI Slope}

Only $1 \%$ of arctic Alaska ecosystem areas (nearly $2670 \mathrm{~km}^{2}$ ) were detected with significant negative growing season EVI trends, largely clustered on the Arctic Coastal Plain, north and east of $69^{\circ} \mathrm{N}$ and $154^{\circ} \mathrm{W}$, which included northern portions of the Arctic National Wildlife Refuge (Figure 4). Areas detected with the most significant negative growing season EVI trends $\left(<-0.04\right.$ units $\left.\cdot \mathrm{yr}^{-1}\right)$ were detected within the perimeter of the Anaktuvuk River wildfire (centered at $69.13^{\circ} \mathrm{N}, 150.61^{\circ} \mathrm{W}$ ), which burned $1040 \mathrm{~km}^{2}$ of tundra shrubland in the central Arctic Foothills during October, 2007. The time series of monthly MODIS EVI sampled from within this wildfire perimeter showed the nearly complete loss of green vegetation cover within the fire perimeter in late 2007, followed by steady regrowth in the subsequent years (Figure 5(a)).

Non-forested wetlands (marshes, bogs, fens, and floodplains) were co-located on $1467 \mathrm{~km}^{2}$ (55\%) of the total area detected with significant negative growing season EVI trends in the Alaskan arctic region. The vast majority (99\%) of these non-forested wetlands with significant negative EVI trends were classified as palustrine emergent vegetation (herbaceous cover of sedges and grasses; Cowardin et al., [26]). Elevation co-varied with the areas of significant negative EVI slope, showing that $90 \%$ such areas were located at less than $500 \mathrm{~m}$; another $9 \%$ located at higher than $1000 \mathrm{~m}$. All of the arctic Alaska areas detected with significant negative growing season EVI trends were classified with coverage of continuous permafrost cover.

To more closely examine ecosystems of arctic Alaska that have declined significantly in growing season greenness over the past decade, representative areas of tundra cover that were unburned since the 1940s were identified in the northern foothills of the Arctic National Wildlife Refuge (near $69.70^{\circ} \mathrm{N},-143.43^{\circ} \mathrm{W}$ ). The MODIS bi-weekly time series from 2000 to 2010 showed a steady decline in green cover beginning in 2004 (Figure 5(b)). Because the vegetation had not burned over at least the previous 60 years (AICC historical fire data, circa 2010), such declines detected in growing season greenness for these areas could not be attributed to vegetation loss from recent wildfires. Approximately $1630 \mathrm{~km}^{2}$ of arctic Alaska ecosystems fell into this category of declining green vegetation cover outside of recent wildfires boundaries.

\subsection{Positive EVI Slope}

Out of a total of $178,050 \mathrm{~km}^{2}$ in the arctic Alaska region detected with significant positive growing season EVI 


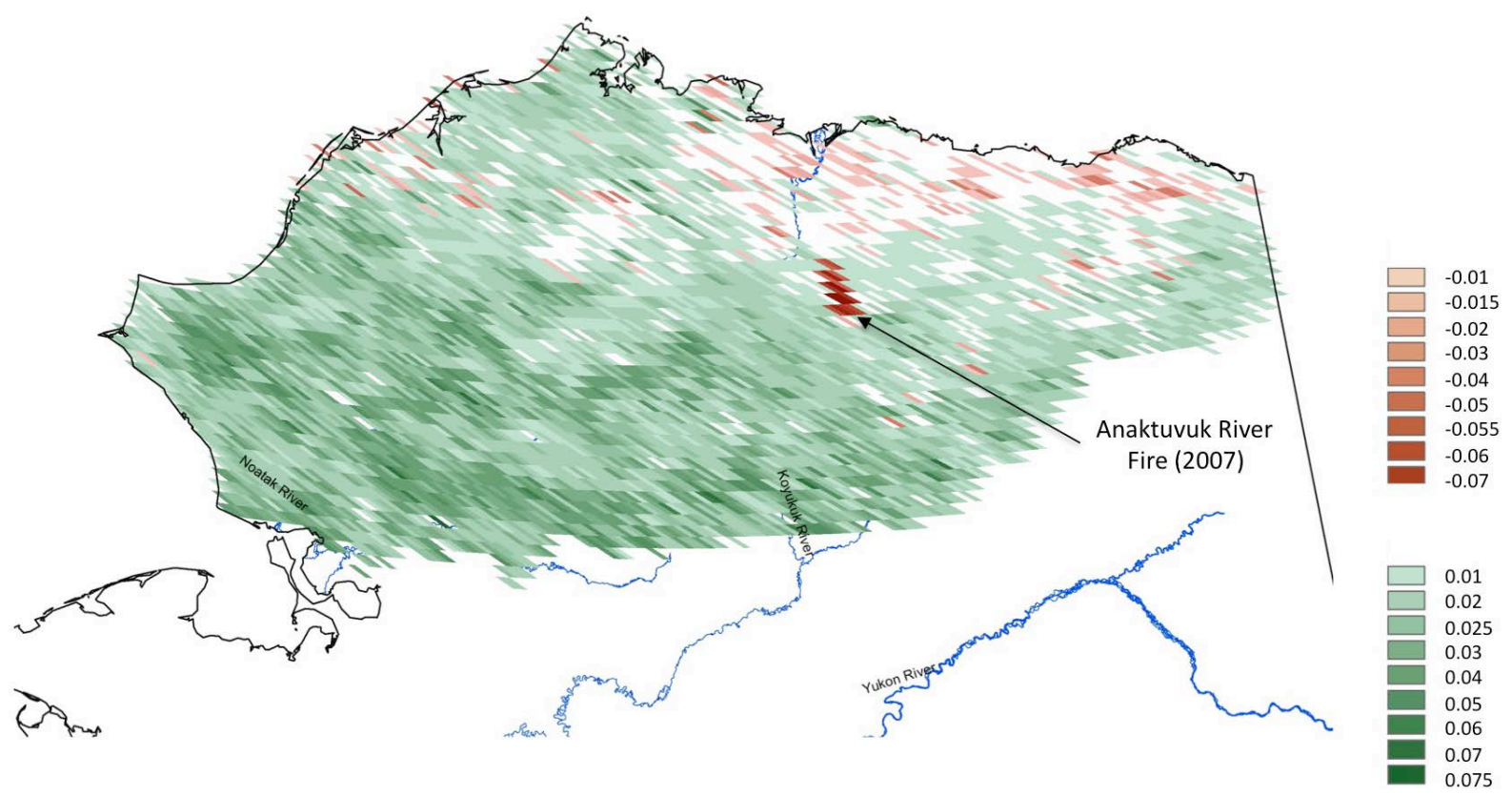

Figure 3. Regional map of MODIS EVI slope results from 2000 to 2010 growing seasons over the arctic Alaska region. Negative slope categories indicated a decline in vegetation cover, whereas positive slope categories indicated a growth of vegetation cover.

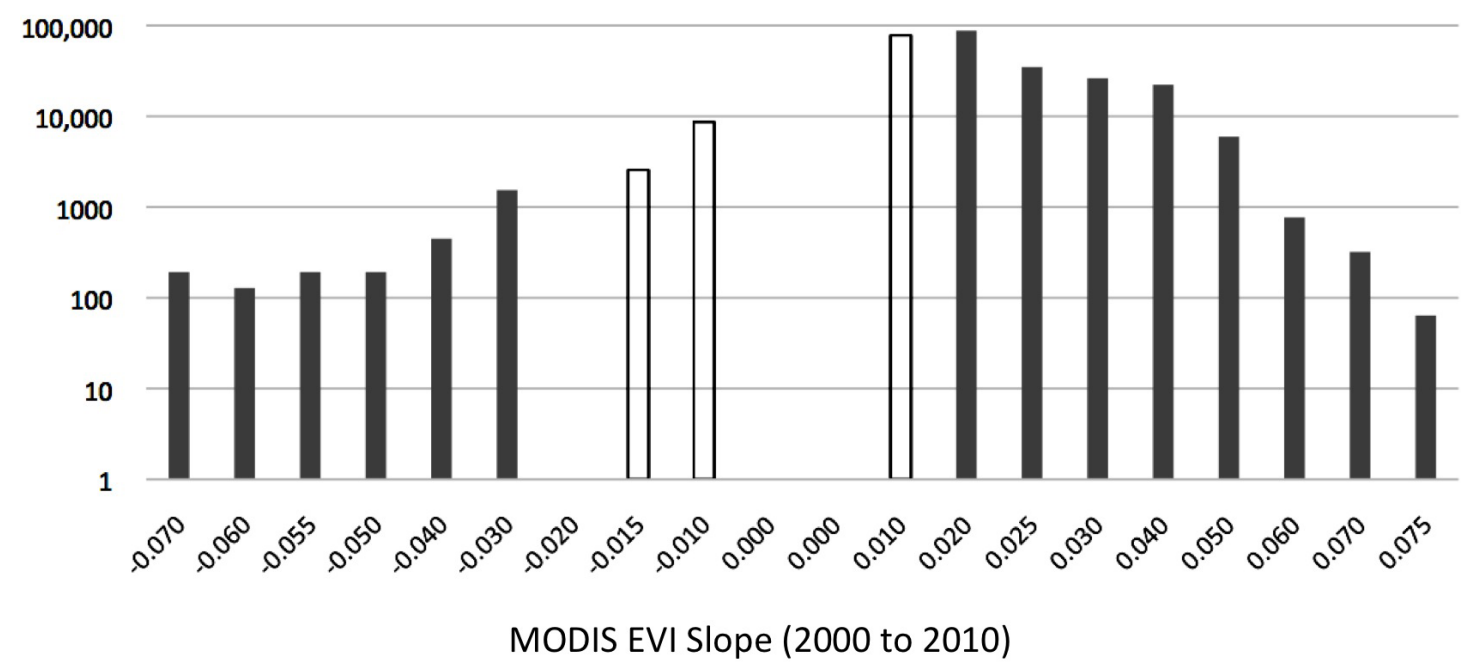

Figure 4. Frequency distribution (on a logarithmic scale) of MODIS EVI slope results from 2000 to 2010 growing seasons for $8 \times 8 \mathrm{~km}$ areas over the arctic Alaska region. Negative slope categories indicated a decline in vegetation cover, whereas positive slope categories indicated a growth of vegetation cover. Shaded slope categories were significant at $p<0.05$.

trends (Figure 3), only 1\% (1678 $\left.\mathrm{km}^{2}\right)$ were located in areas that had been burned by wildfires since the 1940s. Areas burned during the 1970s represented 44\% of these positive EVI trends, while areas burned between 1990 and 2010 represented $41 \%$ of the total positive growing season EVI trends in arctic Alaska.

In contrast to areas detected in the arctic Alaska region with negative EVI trends, the vast majority $(>90 \%)$ of areas detected with significant positive growing season EVI trends were classified as upland (non-wetland) tundra cover. Non-forested wetlands were co-located on only $8 \%\left(14,000 \mathrm{~km}^{2}\right)$ of the total area detected with significant positive growing season EVI trends. One-half of these non-forested wetlands with significant positive EVI trends were classified as palustrine emergent vegetation and the other half as palustrine wooded (shrub) vegetation. 


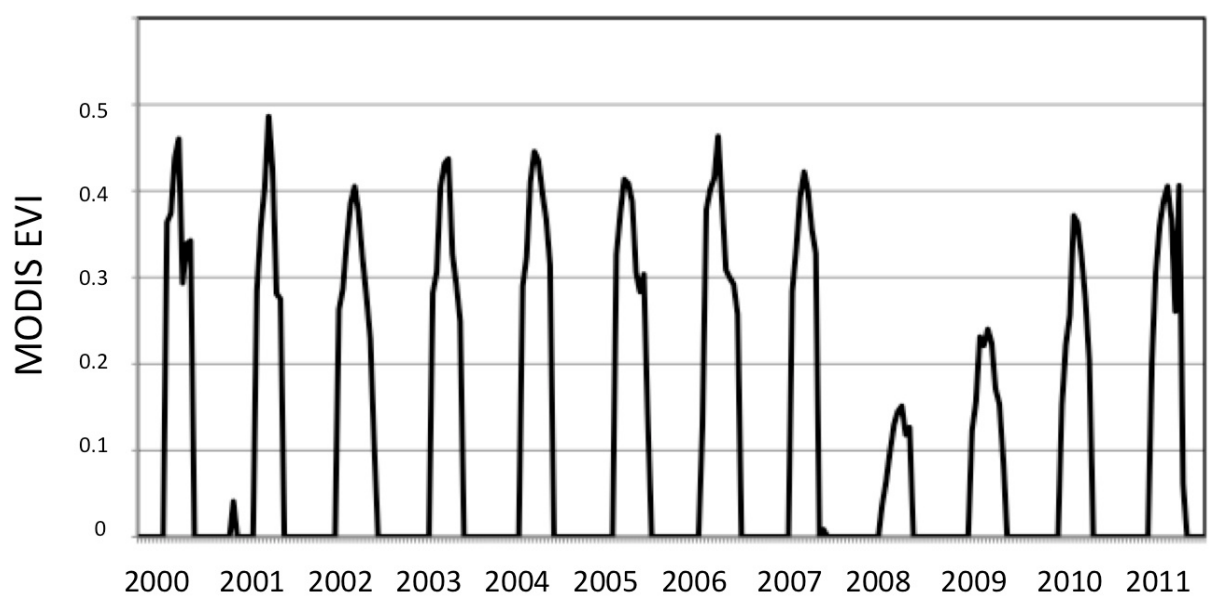

(a)

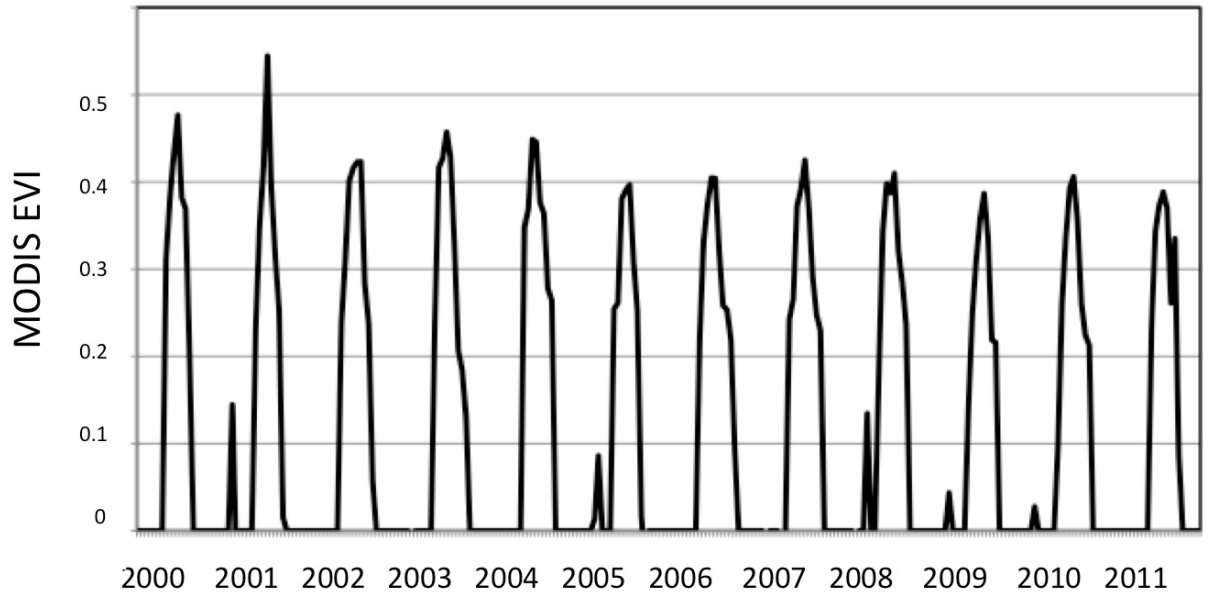

(b)

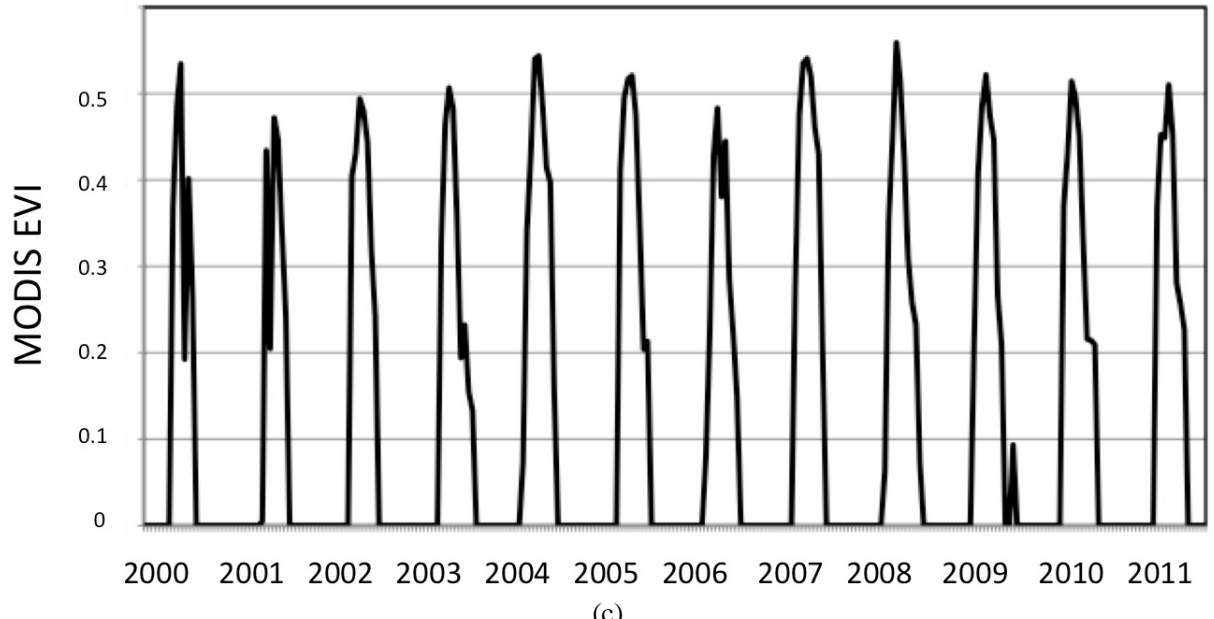

(c)

Figure 5. MODIS bi-weekly EVI composite for (a) burned arctic tundra $\left(69.0567^{\circ} \mathrm{N}\right.$, $-150.5231^{\circ} \mathrm{W}$ ) within the Anaktuvuk River wildfire boundary of 2007 ; (b) unburned tundra vegetation cover identified with a significant negative growing season EVI slope, located within the Arctic National Wildlife Refuge $\left(69.7025^{\circ} \mathrm{N},-143.4251^{\circ} \mathrm{W}\right)$; and (c) unburned tundra $\left(66.5011^{\circ} \mathrm{N}, 144.6069^{\circ} \mathrm{W}\right)$ vegetation cover identified with a significant positive growing season EVI slope, located within the Kobuk Valley National Park in the western Brooks Range $\left(67.5799^{\circ} \mathrm{N},-160.1490^{\circ} \mathrm{W}\right)$. 
As with areas detected in the arctic Alaska region with negative EVI trends, elevation co-varied with the areas of significant positive EVI slope, showing that $86 \%$ such areas were located at less than $500 \mathrm{~m}$; another $4 \%$ located at higher than $1000 \mathrm{~m}$. The majority (94\%) of the arctic Alaska area detected with significant positive growing season EVI trends was classified with coverage of continuous permafrost.

To more closely examine ecosystems of arctic Alaska that have increased significantly in growing season greenness over the past decade, representative areas of upland tundra cover that were unburned since the 1940s were identified within Kobuk Valley National Park (NP) in the western Brooks Range. This protected area between the Selawik National Wildlife Refuge and the Noatak National Preserve is noted for its historic caribou migration routes. The MODIS bi-weekly time series from 2000 to 2010 showed a steady increase in green cover after 2001, with growing seasons extending further and further into September after 2004 (Figure 5(c)). These upland areas were in undulating terrain (between 400 and $700 \mathrm{~m}$ elevation), underlain by continuous permafrost. Similar locations showing significant increases in growing season greenness over the past decade were detected within the southern Cape Krusenstern National Monument $\left(67.42^{\circ} \mathrm{N},-163.66^{\circ} \mathrm{W}\right)$, the Noatak National Preserve $\left(68.22^{\circ} \mathrm{N},-158.72^{\circ} \mathrm{W}\right)$, the Gates of the Arctic NP $\left(67.52^{\circ} \mathrm{N},-153.54^{\circ} \mathrm{W}\right)$, and the south-central Arctic National Wildlife Refuge (near $68.41^{\circ} \mathrm{N},-144.86^{\circ} \mathrm{W}$ ). Because the vegetation had not burned over at least the previous 60 years (AICC historical fire data, circa 2010), these increases detected in growing season greenness for such locations could not attributed to rapid regrowth after recent wildfires. Approximately $176,370 \mathrm{~km}^{2}$ of arctic Alaska ecosystems fell into this category of significantly increasing green vegetation cover outside of recent wildfires boundaries.

\section{Discussion}

The MODIS EVI time-series data analyzed in this study provided a consistent large-scale metric of vegetation growth or decline trends across the arctic Alaska region. Among the relatively small coverage areas of growing season EVI decline trends within the region over the years 2000 to 2010, less than $50 \%$ could be explained by the recent (since 2000) impacts of wildfire. A notable fraction of non-forested wetlands were detected with significant negative growing season EVI trends on the arctic coastal plain and foothills.

On a watershed scale, Jorgenson et al. [27] used photointerpretation of arctic Alaska to classify ice-wedge degradation processes. In advanced stages of thawing, water-filled pits can form following the loss of a thin protective soil layer in tussock tundra and sedge marshes. Watershed studies by Bowden et al. [28] in the foothills of the Brooks Range implied that, under a warming climate in the Arctic, it is likely that small disturbances to surface soils and vegetation may promote accelerated subsurface warming that could lead to thermokarsting (subsidence of the surface), and in hilly or mountainous terrain could have important impacts on the stream ecosystems and headwater areas they drain.

Remote sensing analysis in the river valleys of Interior Alaska by Belshe et al. [29] led to the conclusion that, despite the thermal protection provided by the extensive organic soil accumulations, this insulation property is no longer sufficient under present climate conditions to keep the underlying (near-surface) permafrost from thawing and thermokarst from forming and expanding. With climate warming, an unfrozen soil layer can form, with water draining laterally on slopes, or forming pits, ponds, and fens on flatter lowland terrain. Vegetation change from thawing and permafrost collapse in lowland stands may follow one of (at least) two different pathways [30]: 1) tree mortality by "drowning" in stands adjacent to groundwater fens, with development of forbdominated floating mats, or 2) tree loss into collapsed water-filled thaw pits, with colonization by early successional Sphagnum bog species under acidic conditions. These thermokarst-driven pathways of woody vegetation loss best explain the EVI decline trends detected outside of recent wildfire boundaries in the results presented above across the arctic Alaska region.

Succession and vegetation regrowth after wildfire did not account for a significant portion of the area of positive EVI growing season trends in the arctic Alaska region. Rather, unburned upland tundra of the western Brooks Range showed a particularly high coverage of positive EVI slope areas. From the results presented above, which expand upon the findings of Potter et al. [14], we hypothesize that temperature (warming) has enhanced the rates of upland tundra vegetation growth across arctic Alaska over recent years. In support of this hypothesis, evidence of shrub (alder, birch, and willow) expansion over the last half century has been documented through repeat photography of the past 50 years in Alaska [31]. Beck and Goetz [32] also postulated that the proportion of North America tundra areas increasing in productivity has steadily grown since 1982, reaching 
32\% of non-barren areas by 2008.

Hope et al. [33] and Jia et al. [1] both showed that an increase in satellite VI for tundra ecosystems was strongly associated with an increase in aboveground plant biomass. Nonetheless, increasing tundra biomass does not always merely indicate increasing shrub density, as shown by Beck and Goetz [32], whose detection of a regional greening trend appeared to be unrelated to shrub density. This suggests that tundra productivity may be increasing across a range of functional vegetation types in Alaska, including herbaceous cover.

The causal mechanisms of tundra growth enhancement were suggested by Tape et al. [31] as warming temperatures and deeper snow packs in recent years, which can promote increased microbial activity, which in turn can increase the availability of nutrients for plant uptake, particularly by small shrubs. Consistent with our MODIS EVI trend results from 2000 to 2010, the most notable expansions of shrubs detected by the photo-interpretations of these authors in Alaska were in geomorphic units subjected to regular non-fire disturbances in relative moist upland tundra.

Several consequences of changing tundra vegetation were reviewed by Sturm et al. [34]. More relatively dark-colored shrubs emerging above winter snow cover may reduce surface albedo and increase solar energy absorbed at the surface. Because shrubs allocate carbon to woody stems that have long turnover times compared with annual roots and the leaves of graminoid plant forms, increasingly shrub-dominated tundra is likely to assimilate carbon in a different way and store it for a different length of time than graminoid-dominated tundra [35]. Expansion of shrubland cover in arctic Alaska may also be altering forage quantity and quality for caribou herds [36].

In closing, it is worth noting that Wang et al. [37] reported on sensor degradation having had an impact on trend detection in North America boreal and tundra zone NDVI with Collection 5 data from MODIS. The main impacts of gradual blue band (Band 3, $470 \mathrm{~nm}$ ) degradation on simulated surface reflectance was most pronounced at near-nadir view angles, leading to a small decline $\left(0.001-0.004 \mathrm{yr}^{-1}\right.$; $5 \%$ overall between 2002 and 2010) in NDVI under a range of simulated aerosol conditions and high-latitude surface types. Even if this same sensor degradation problem affected MODIS EVI trends over the period of our analysis from 2000 to 2010, the apparent rate of greening in warming ecosystems of interior Alaska was not negated by such small, progressive changes in MODIS data quality. The methodology developed for mapping and characterization of arctic ecosystem growth trends in this study can be readily extended to other regions of the arctic-boreal zone, and over the next decade of Collection 6 MODIS data.

\section{Conclusion}

Ecosystems of arctic Alaska that have increased significantly in growing season greenness over the past decade were identified within Kobuk Valley NP in the western Brooks Range between the Selawik National Wildlife Refuge and the Noatak National Preserve. These upland areas were in undulating terrain (between 400 and 700 $\mathrm{m}$ elevation), underlain by continuous permafrost. Similar locations showing significant increases in growing season greenness over the past decade were identified for future ground-based monitoring studies within the southern Cape Krusenstern National Monument, the Noatak National Preserve, the Gates of the Arctic NP, and the south-central Arctic National Wildlife Refuge.

\section{Acknowledgements}

This work was conducted with the support from NASA under the US National Climate Assessment.

\section{References}

[1] Jia, G.J., Epstein, H.E. and Walker, D.A. (2003) Greening of Arctic Alaska, 1981-2001. Geophysical Research Letters, 30, 2067. http://dx.doi.org/10.1029/2003GL018268

[2] Callaghan, T.V., Björn, L.O., Chapin III, F.S., Chernov, Y., Christensen, T.R., Huntley, B., Ims, R., Johansson, M., Riedlinger, D.J., Jonasson, S., Matveyeva, N., Oechel, W., Panikov, N. and Shaver, G. (2005) Arctic Tundra and Polar Desert Ecosystems. Arctic Climate Impact Assessment, Arctic Council, Cambridge University, Cambridge, 243-352.

[3] Reist, J.D., Wrona, F.J., Prowse, T.D., Power, M., Dempson, J.B., Beamish, R.J., King, J.R., Carmichael, T.J. and Sawatzky, C.D. (2006) General Effects of Climate Change on Arctic Fishes and Fish Populations. Ambio, 35, 370-380. http://dx.doi.org/10.1579/0044-7447(2006)35[370:GEOCCO]2.0.CO;2

[4] Martin, P.D., Jenkins, J.L., Adams, F.J., Jorgenson, M.T., Matz, A.C., Payer, D.C., Reynolds, P.E., Tidwell, A.C. and 
Zelenak, J.R. (2009) Wildlife Response to Environmental Arctic Change: Predicting Future Habitats of Arctic Alaska. Report of the Wildlife Response to Environmental Arctic Change (WildREACH): Predicting Future Habitats of Arctic Alaska Workshop, US Fish and Wildlife Service, Fairbanks, 138 p.

[5] Markon, C.J., Trainor, S.F. and Chapin III, F.S., Eds. (2012) The United States National Climate Assessment—Alaska Technical Regional Report. US Geological Survey Circular, 148.

[6] Shulski, M. and Wendler, G. (2007) The Climate of Alaska. University of Alaska Press, Fairbanks, p. 214.

[7] Xu, L., Myneni, R.B., Chapin III, F.S., Callaghan, T.V., Pinzon, J.E., Tucker, C.J., Zhu, Z., Bi, J., Ciais, P., Tømmervik, H., Euskirchen, E.S., Forbes, B.C., Piao, S.L., Anderson, B.T., Ganguly, S., Nemani, R.R., Goetz, S., Beck, P.S.A., Bunn, A.G., Cao, C. and Stroeve, J.C. (2013) Temperature and Vegetation Seasonality Diminishment over Northern Lands. Nature Climate Change, 3, 581-586. http://dx.doi.org/10.1038/nclimate1836

[8] Zeng, H. and Jia, G. (2013) Impacts of Snow Cover on Vegetation Phenology in the Arctic from Satellite View. Advances in Atmospheric Sciences, 30, 1421-1432. http://dx.doi.org/10.1007/s00376-012-2173-x

[9] Amiro, B.D., Chen, J.M. and Liu, J. (2000) Net Primary Productivity Following Forest Fire for Canadian Ecoregions. Canadian Journal of Forest Research, 30, 939-947. http://dx.doi.org/10.1139/x00-025

[10] Epting, J. and Verbyla, D.L. (2005) Landscape Level Interactions of Pre-Fire Vegetation, Burn Severity, and Post-Fire Vegetation over a 16-Year Period in Interior Alaska. Canadian Journal of Forest Research, 35, 1367-1377. http://dx.doi.org/10.1139/x05-060

[11] Cuevas-Gonzalez, M., Gerard, F., Balzter, H. and Riano, D. (2009) Analysing Forest Recovery after Wildfire Disturbance in Boreal Siberia Using Remotely Sensed Vegetation Indices. Global Change Biology, 15, 561-577. http://dx.doi.org/10.1111/j.1365-2486.2008.01784.x

[12] Casady, G.M. and Marsh, S.E. (2010) Broad-Scale Environmental Conditions Responsible for Post-Fire Vegetation Dynamics. Remote Sensing, 2, 2643-2664. http://dx.doi.org/10.3390/rs2122643

[13] Li, S. and Potter, C.S. (2012) Vegetation Regrowth Trends in Post Forest Fire Ecosystems across North America from 2000 to 2010. Natural Sciences, 4, 755-770. http://dx.doi.org/10.4236/ns.2012.410100

[14] Potter, C., Li, S. and Crabtree, R. (2013) Changes in Alaskan Tundra Ecosystems Estimated from MODIS Greenness Trends, 2000 to 2010. Journal of Geophysics \& Remote Sensing, 2, 107. http://dx.doi.org/10.4172/2169-0049.1000107

[15] Goetz, S.J., Bunn, A.G., Fiske, G.J. and Houghton, R.A. (2005) Satellite Observed Photosynthetic Trends across Boreal North America Associated with Climate and Fire Disturbance. Proceedings of the National Academy of Sciences, 103, 13521-13525. http://dx.doi.org/10.1073/pnas.0506179102

[16] Goetz, S.J., Fiske, G.J. and Bunn, A.G. (2006) Using Satellite Time-Series Data Sets to Analyze Fire Disturbance and Forest Recovery across Canada. Remote Sensing of Environment, 101, 352-365. http://dx.doi.org/10.1016/j.rse.2006.01.011

[17] Kim, Y., Kimball, J.S., Zhang, K. and McDonald, K.C. (2012) Satellite Detection of Increasing Northern Hemisphere Non-Frozen Seasons from 1979 to 2008: Implications for Regional Vegetation Growth. Remote Sensing of Environment, 121, 472-487. http://dx.doi.org/10.1016/j.rse.2012.02.014

[18] Heidinger, A.K., Ann, V.R. and Dean, C. (2002) Using MODIS to Estimate Cloud Contamination of the AVHRR Data Records. Journal of Atmospheric and Oceanic Technology, 19, 586-601. http://dx.doi.org/10.1175/1520-0426(2002)019<0586:UMTECC >2.0.CO;2

[19] Whitcomb, J., Moghaddam, M., McDonald, K., Kellndorfer, J. and Podest, E. (2009) Mapping Wetlands of Alaska from L-Band SAR Imagery. Canadian Journal of Remote Sensing, 35, 54-72. http://dx.doi.org/10.5589/m08-080

[20] LP-DACC: NASA Land Processes Distributed Active Archive Center (2007) MODIS/Terra Vegetation Indices Monthly L3 Global 0.05Deg CMG (MOD13C2), Version 005. USGS/Earth Resources Observation and Science (EROS) Center, Sioux Falls.

[21] Huete, A., Didan, K., Miura, T., Rodriquez, E., Gao, X. and Ferreira, L. (2002) Overview of the Radiometric and Biophysical Performance of the MODIS Vegetation Indices. Remote Sensing of Environment, 83, 195-213. http://dx.doi.org/10.1016/S0034-4257(02)00096-2

[22] Friedl, M.A., McIver, D.K., Hodges, J.C.F., Zhang, X.Y., Muchoney, D., et al. (2002) Global Land Cover Mapping from MODIS: Algorithms and Early Results. Remote Sensing of Environment, 83, 287-302. http://dx.doi.org/10.1016/S0034-4257(02)00078-0

[23] Ferrians, O.J. (1965) Permafrost Map of Alaska. US Geological Survey, Miscellaneous Geologic Investigations Map I-445, Scale 1:2,500,000.

[24] Miller, J.A., Whitehead, R.L., Gingerich, S.B., Oki, D.S. and Olcott, P.G. (1999) Ground Water Atlas of the United States: Segment 13, Alaska, Hawaii, Puerto Rico and the US Virgin Islands. US Geological Survey Hydrologic Investigations Atlas HA-730-N, 36 p. 
[25] USDA Natural Resources Conservation Service (2006) Land Resource Regions and Major Land Resource Areas (MRLAs) of the United States, the Caribbean and the Pacific Basin. US Department of Agriculture Handbook 296.

[26] Cowardin, L.M., Carter, V., Golet, F.C. and LaRoe, E.T. (1997) Classification of Wetlands and Deepwater Habitats of the United States. Office of Biological Services, Fish and Wildlife Service, FWS/OBS-79/31.

[27] Jorgenson, M.T., Shur, Y.L. and Pullman, E.R. (2006) Abrupt Increase in Permafrost Degradation in Arctic Alaska. Geophysical Research Letters, 33, Article ID: L02503. http://dx.doi.org/10.1029/2005GL024960

[28] Bowden, W.B., Gooseff, M.N., Balser, A., Green, A., Peterson, B.J. and Bradford, J. (2008) Sediment and Nutrient Delivery from Thermokarst Features in the Foothills of the North Slope, Alaska: Potential Impacts on Headwater Stream Ecosystems. Journal of Geophysical Research, 113, Article ID: G02026. http://dx.doi.org/10.1029/2007JG000470

[29] Belshe, E.F., Schuur, E.A.G. and Grosse, G. (2013) Quantification of Upland Thermokarst Features with High Resolution Remote Sensing. Environmental Research Letters, 8. http://dx.doi.org/10.1088/1748-9326/8/3/035016

[30] Racine, C.H., Jorgenson, M.T. and Walters, J.C. (1998) Thermokarst Vegetation in Lowland Birch Forests on the Tanana Flats, Interior Alaska, USA. In: Lewkowicz, A.G. and Allard, M., Eds., Proceedings of the Seventh International Conference on Permafrost, Quebec, 23-27 June 1998, 927-933.

[31] Tape, K., Sturm, M. and Racine, C. (2006) The Evidence for Shrub Expansion in Northern Alaska and the Pan-Arctic. Global Change Biology, 12, 686-702. http://dx.doi.org/10.1111/j.1365-2486.2006.01128.x

[32] Beck, P.S.A. and Goetz, S.J. (2011) Satellite Observations of High Northern Latitude Vegetation Productivity Changes between 1982 and 2008: Ecological Variability and Regional Differences. Environmental Research Letters, 6, Article ID: 045501. http://dx.doi.org/10.1088/1748-9326/6/4/045501

[33] Hope, A.S., Kimball, J.S. and Stow, D.A. (1993) The Relationship between Tussock Tundra Spectral Reflectance Properties and Biomass and Vegetation Composition. International Journal of Remote Sensing, 14, 1861-1874. http://dx.doi.org/10.1080/01431169308954008

[34] Sturm, M., Schimel, J., Michaelson, G., Welker, J.M., Oberbauer, S.F., Liston, G.E., Fahnestock, J. and Romanovsky, V.E. (2005) Winter Biological Processes Could Help Convert Arctic Tundra to Shrubland. Bioscience, 55, 17-26. http://dx.doi.org/10.1641/0006-3568(2005)055[0017:WBPCHC]2.0.CO;2

[35] Oechel, W.C., Vourlitis, G.L., Hastings, S.J., Zulueta, R.C., Hinzman, L.D. and Kane, D.L. (2000) Acclimation of Ecosystem $\mathrm{CO}_{2}$ Exchange in the Alaskan Arctic in Response to Decadal Climate Warming. Nature, 406, 978-981. http://dx.doi.org/10.1038/35023137

[36] Johnstone, J., Russell, D.E. and Griffith, B. (1999) Variations in Plant Forage Quality in the Range of the Porcupine Caribou Herd. Rangifer, 22, 83-92.

[37] Wang, D., Morton, D., Masek, J., Wu, A., Nagol, J., Xiong, X., Levy, R., Vermote, E. and Wolfe, R. (2012) Impact of Sensor Degradation on the MODIS NDVI Time Series. Remote Sensing of Environment, 119, 55-61.

http://dx.doi.org/10.1016/j.rse.2011.12.001 
Scientific Research Publishing (SCIRP) is one of the largest Open Access journal publishers. It is currently publishing more than 200 open access, online, peer-reviewed journals covering a wide range of academic disciplines. SCIRP serves the worldwide academic communities and contributes to the progress and application of science with its publication.

Other selected journals from SCIRP are listed as below. Submit your manuscript to us via either submit@scirp.org or Online Submission Portal.
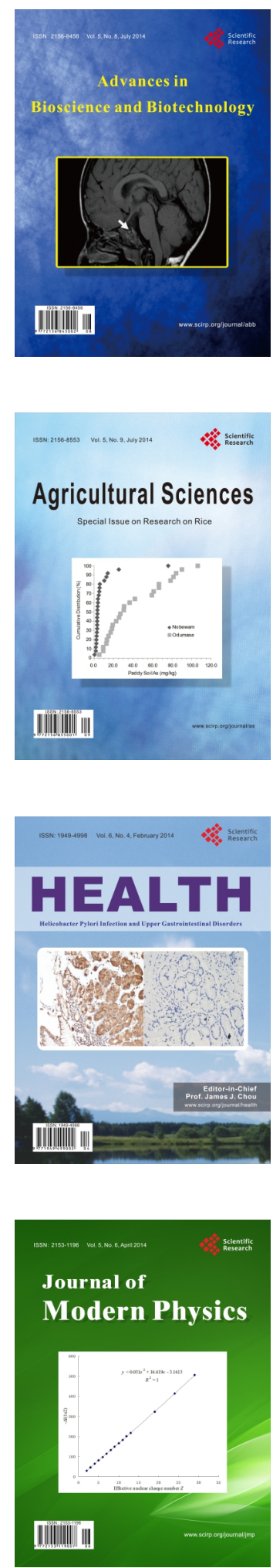
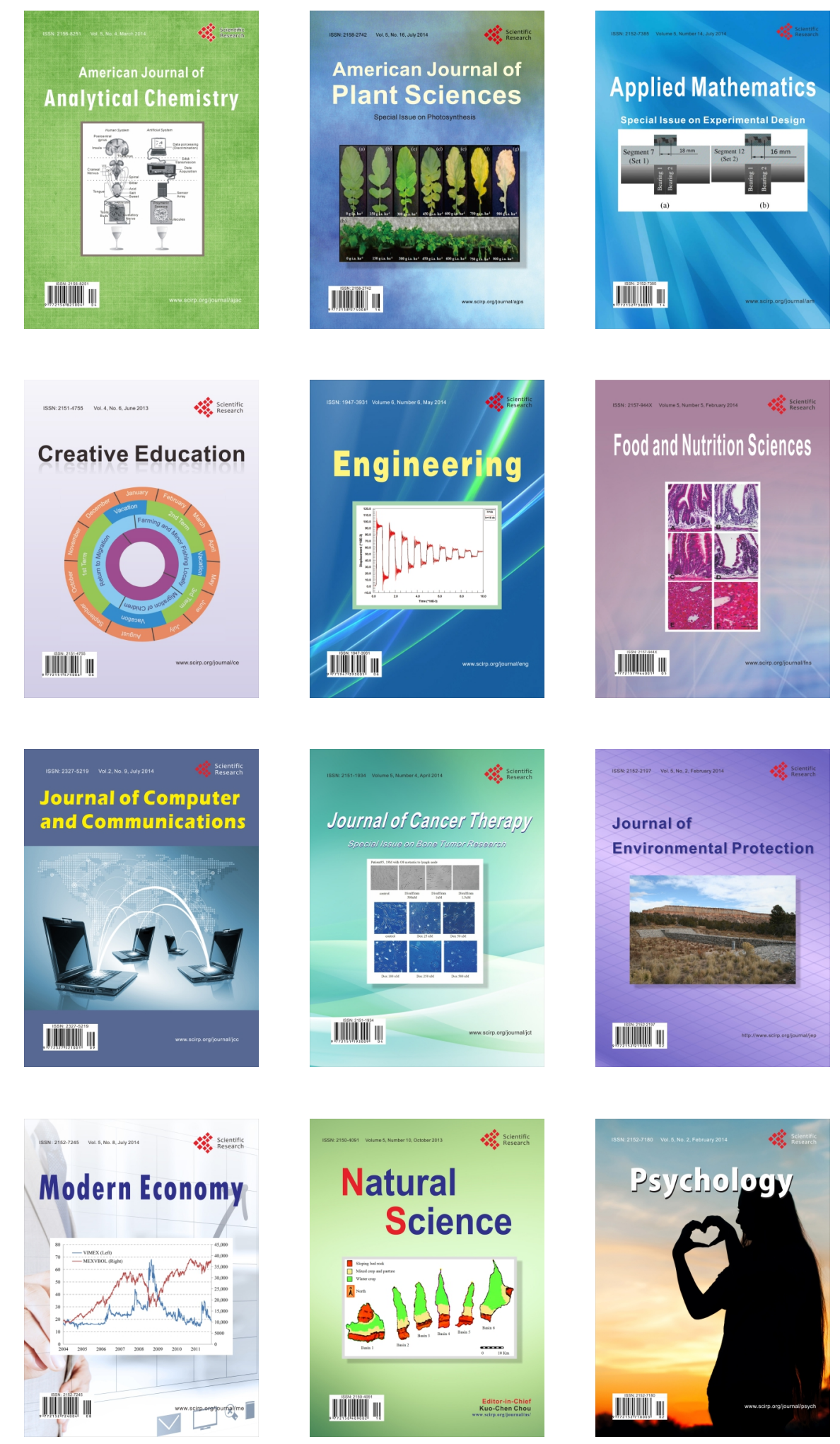